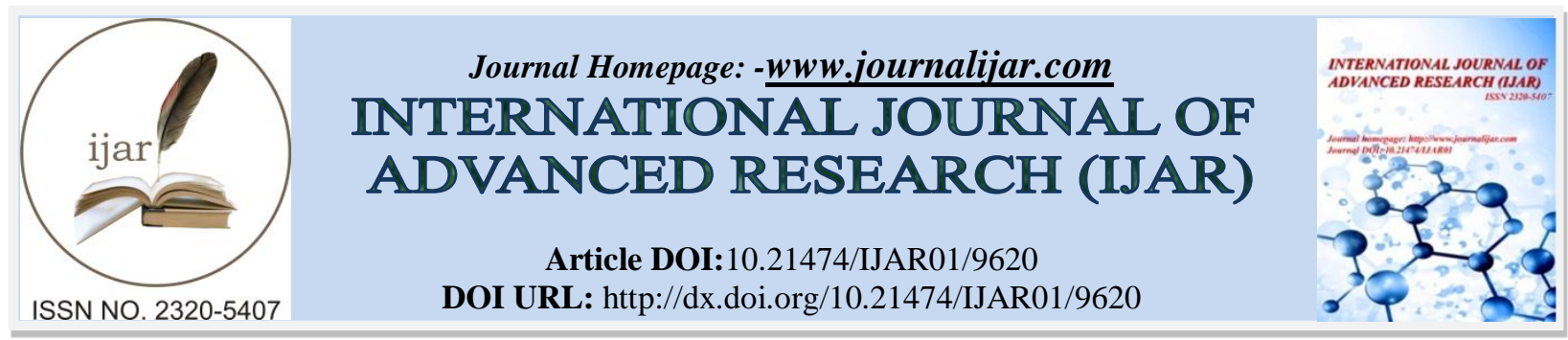

RESEARCH ARTICLE

\title{
VARIATION IN WATER QUALITY INDEX (WQI) BY THE EFFECTS OF IDOL IMMERSION ON THE WATER QUALITY PARAMETERS OF DULAHRA POND IN RATANPUR IN CHHATTISGARH.
}

Dr.Renu Nayar.

Department of Chemistry D.P.Vipra College Bilaspur C.G.

\section{Manuscript Info}

\section{Manuscript History}

Received: 20 June 2019

Final Accepted: 22 July 2019

Published: August 2019

Keywords

Physicochemical analysis, WQI, Idol immersion, pond water pollution, festivals.

\section{Abstract}

The present work aims at analysing the water quality index (WQI) in the Dulahra pond water situated in Ratanpur city in Bilaspur District in Chhattisgarh by monitoring four direction [north, west, east south ]in sampling locations around the Dulahra pond for a period of 3 months from September to November-2018. For calculating the WQI, 14 parameters, namely, $\mathrm{pH}$, electrical conductivity, total dissolved solids, Total suspended, Total Hardness Alkalinity, Dissolved oxygen, BOD, COD. Nitrates fluoride and transparency were analysed. It is apparent from WQI values that Dulahra pond water with WQI values ranging from 62.28 to 69.84 (pre-immersion period), 58.27to 64.16(immersion period) and 38.27to 44.16 (post-immersion period falls under simply good to poor water category. It was observed that the values of physicochemical parameters decrease in the pre-immersion and immersion period, and significantly increased during the immersion period for $\mathrm{pH}$, total dissolved solids, Total Hardness, Alkalinity, COD , Nitrates however the general trend observed was: Immersion > Post immersion > Pre-immersion values. The present work showed maximum values found during Post immersion period for EC,BOD, Chloride, fluoride Sulphate,. (Post immersion > immersion > Preimmersion values ) The present study revealed that Dulahra pond water is polluted due to immersion of idols of God and Goddess during festival season ,human activity ,surface run-off, bathing activities, agriculture run-off, effluents from upstream from surrounding industrial and garden area, immersion of idols of God and Goddess during festival season, and is unsuitable for human consumption, industrial purpose also for the survival of life forms unless treated properly. The low value of DO and BOD and Total Solids levels at different sites indicate the poor water quality due to idol immersion.

Copy Right, IJAR, 2019,. All rights reserved.

\section{Introduction:-}

The demand for water has increased over the years and this has led to water scarcity in many parts of the world. The situation is aggravated by the problem of water pollution or contamination. India is heading towards a fresh water crisis mainly due to improper management of water resources and environmental degradation, which has led to lack of access to safe water supply to millions of people. Water is one of the earth's most important resources that use for 
human life and it's quality is totally depend on geological environment, recovery, utilization as per need and human activities like domestic, industrial or commercial, mining operations, agricultural etc. ${ }^{1}$ Today is most of the surface and subsurface water bodies are unfortunately under the environmental stress due to increase in population, advance agrochemicals and urbanization are used. So there is a high risk of contamination of water by percolation, surface runoff. A Water Quality Index (WQI) is a measure by which water quality can be estimated for various purposes ${ }^{2}$. WOI can be used to predict whether the water is suitable for drinking purpose, industrial purpose or aquatic organisms etc. WQI can be measured on the scale 0 to 100 . Higher the WQI, better is the quality of water. WQI gets affected by various water quality parameters. In this paper effect of $\mathrm{pH}$, Temperature, electrical conductivity, total dissolved solids, Total suspended, Total Hardness, Alkalinity, Dissolved oxygen, BOD, COD, Chloride and Transparency is analyzed.

Ratanpur is situated about $25 \mathrm{~km}$ from Bilaspur. It is the famous holy place. The town Ratanpur is attractive as a religious canter and more than 150 Ponds situated during ancient period as cited in history. Therefore the Ratanpur is known as 'Temple City' as well as 'City of Ponds'. The muni mahatmas were camping all the time here. It is said that two types of waves were clearly visible in this pond several times, which were given the name of Ganga Yamuna. Dulahra pond in Chhattisgarhi language means two waves. It is also called the Ganga of Chhattisgarh. The present study showed that every year more than 5000 idols are immersed in Dulahra water bodies alone .Traditionally, the idols were made of mud and painted with natural colours, but now many are made using plaster of paris and coated with harmful paints containing heavy metals, all of which end up in the rivers on Dussehra day.

\section{Study area and Sampling Sites}

The present investigation proposed to investigate the quality of water in Dulahra one of the major pond situated in Ratanpur city and used by people in the form of different activities. To collect water samples from all study sites the specific sampling sites have been determined at the margin and inside the ponds. For large ponds four sampling sites along four directions in the peripheral /marginal area have been located; simultaneously 100 meter inside from the margin two sampling sites at surface and bottom region of water have been located. Sampling sites and the picture of four direction in Dulahra pond

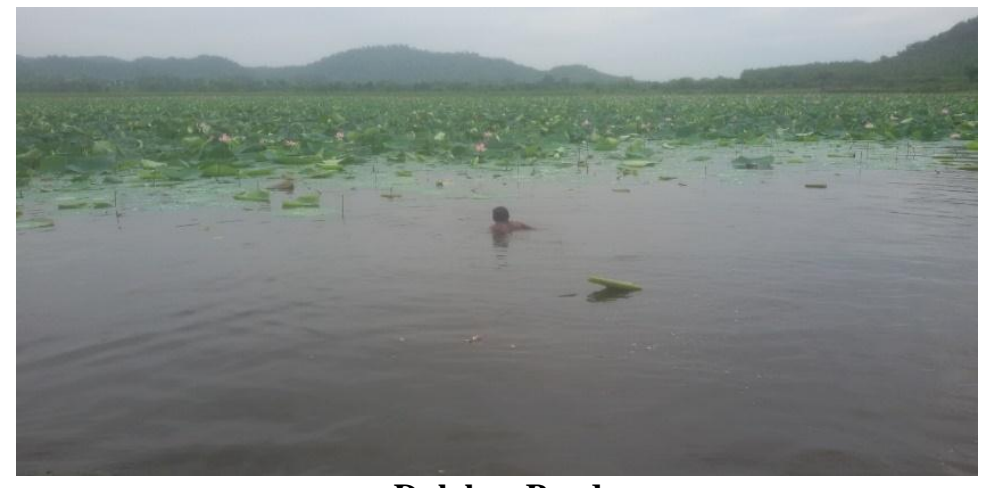

Dulahra Pond

Method and Materials:-

The analysis of the following physico-chemical parameters was carried out : $\mathrm{pH}$, temperature, Electrical conductivity, Transparency, calcium and magnesium hardness, total dissolved solids, total suspended solids, dissolved oxygen (DO), biochemical oxygen demand (BOD), Chemical Oxygen Demand (COD), Chloride, Phosphate and Nitrate

Parameters such as $\mathrm{pH}$, Temperature, EC, TDS, DO were measured at the sample collection sites using Water Quality Analyzer Kit. .Determination of other parameters were carried out by standard methods as prescribed by APHA, Manivaskam and NEERI manual on water and waste water analysis ${ }^{3,4}$. The water samples were collected from each direction at peripheral area. Water was sampled in to $1 \mathrm{~L}$ polyethylene containers. Samples of pond water were collected for chemical analysis from peripheral areas, and inner part during a period from September to November-2018. All water samplings were completed between 10 to 12 o'clock and end of the every month. . Reagents used for the present investigation were of A.R. grade and double distilled water was used for preparing various solution. 
Water quality index (WQI) is of the most important tools to communicate information on the quality of water to the concerned citizens and policy makers. Its provides a comprehensive picture of the quality of surface/ground water for most domestic uses. WQI is defined as a rating that reflects the composite influence of different water quality parameters. Hence, for calculating the WQI in the present study, 13 parameters, namely, $\mathrm{pH}$, electrical conductivity, total dissolved solids, Dissolved oxygen, BOD alkalinity, total hardness, calcium, magnesium, chloride, sulphate, nitrate and phosphate were have been considered. To calculate the water quality index by showing this formulae.

$$
\mathrm{WQI}=\frac{\sum Q n W n}{\sum W n}
$$

Where $\mathrm{Qn}$ is the quality rating, $\mathrm{Wn}$ is the unit weight for the parameters

\section{Result and discussion:-}

Effect of water quality parameters on wqi

pH

$\mathrm{pH}$ is the measure of hydrogen ions in the water. Water has hydrogen ions and hydroxyl ions. When there are equal numbers of both, the water is neutral ${ }^{5}$ Initially, when the $\mathrm{pH}$ is low means water quality is very poor. As the $\mathrm{pH}$ increases till 7 unit, water quality increases and is excellent. Above 7 units of $\mathrm{pH}$, the water quality again starts decreasing and reaches to very poor. Relatively low $\mathrm{pH}$ values may reflect the decreased productivity of the pond as a result of the polluted water discharged into the pond. Variation in $\mathrm{pH}$ in collected pond water sample were 7.2 in September in pre-immersion period 8.3 in immersion time on the month of October and 5.3 obtain in post immersion time in the month of November .

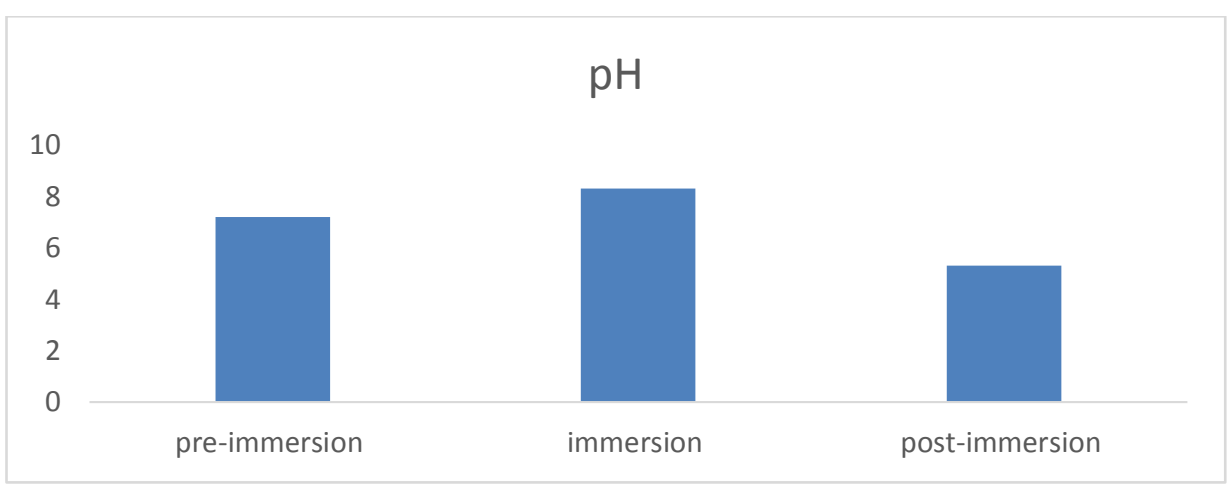

Fig 2:-Average variation in $\mathrm{pH}$ in collected Dulahra pond water

\section{Transparency}

Transparency is parameter of the optical property that cause scattering and absorption of light. Turbidity can be caused by solid suspended matter such as finely divided organic and inorganic matter, clay, slit etc. Transparency is measured by sacchi disc. As the amount of suspended, insoluble particles increases in water, Transparency decreases which in turn decreases water quality. Water was appeared more transparent in the month of august (pre- immersion time) and least transparent in the month of November. (post immersion). Average variation observed in transparency of water sample were $37 \mathrm{~cm}$ (September pre-immersion period); $31 \mathrm{~cm}$ (October, immersion period) and $21 \mathrm{~cm}$ (October, post-immersion period) respectively. 


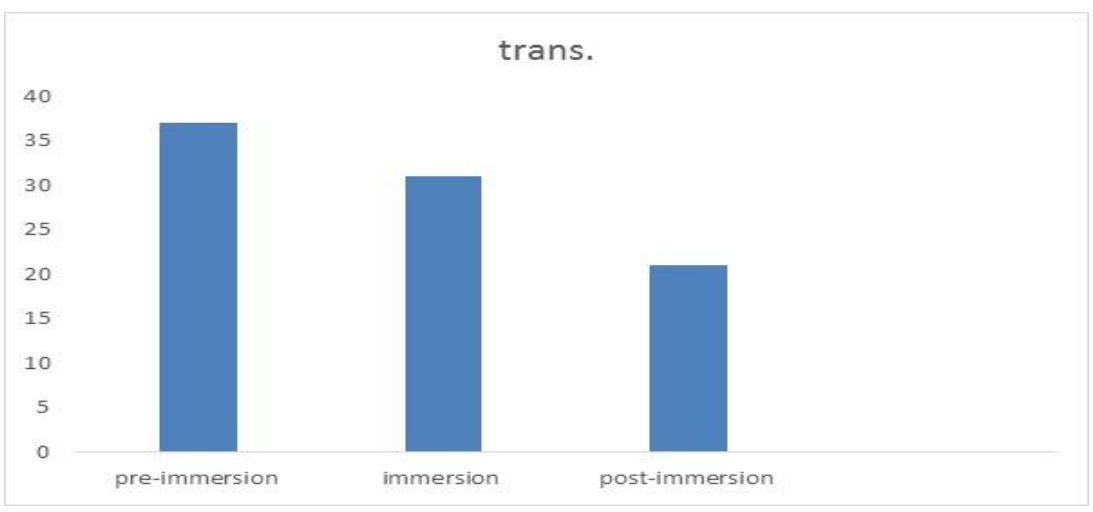

Fig 2:-Average variation in Transparency in collected Dulahra pond water

\section{Dissolved Oxygen (DO)}

DO is the basis of Biological Oxygen Demand test to evaluate pollution potential of wastes. DO is measured in milligrams per litre $(\mathrm{mg} / \mathrm{l}) .{ }^{6}$ Oxygen is the most important gas for most aquatic organisms and for self-purification processes ${ }^{7}$. It is an important parameter which is essential to the metabolism of all aquatic organisms that possess aerobic respiration. Variation in dissolved oxygen (fig 3) in collected water sample were 5.3 to $6.8 \mathrm{mg} / \mathrm{L}$ (September pre-immersion period); 3.8 to $4.9 \mathrm{mg} / \mathrm{L}$ (October, immersion period) and 2.42 to $4.1 \mathrm{mg} / \mathrm{L}$ (October, post-immersion period) respectively. The dissolved oxygen (DO) level at Dulahra pond is $6.38 \mathrm{mg} / \mathrm{l}$ which decreases to $4.8 \mathrm{mg} / \mathrm{l}$ .The acceptable level of DO for a drinking water reservoir is $4 \mathrm{mg} / \mathrm{l} / \mathrm{The}$ low value of DO was due to increase in amount of decomposition of organic matter and effluents of sewage ${ }^{8}$.

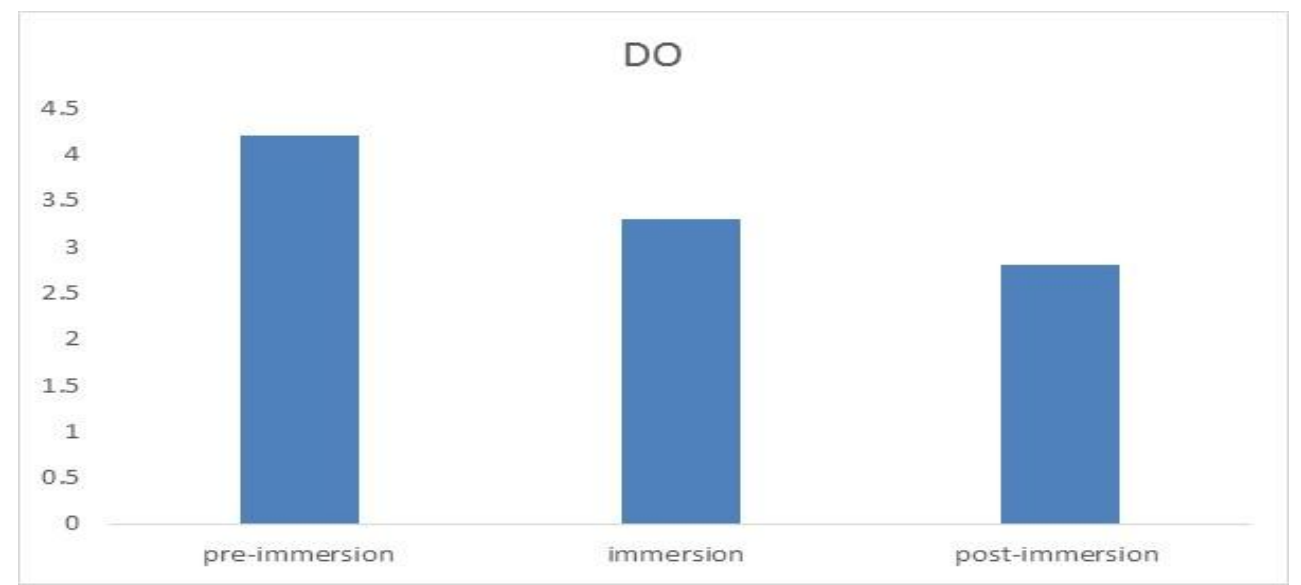

Fig 3:-Average variation in dissolved oxygen in collected Dulahra pond water

\section{Electrical Conductivity (EC)}

Conductivity is a measurement of the ability of an aqueous solution to carry an electrical current. An ion is an atom of an element that has gained or lost an electron which will create a negative or positive state. Conductivity and temperature are directly related. ${ }^{9}$

Water bodies that have an EC value of 50-200 $\mu \mathrm{Scm}-1,200-500 \mu \mathrm{Scm}-1$ and $500-2000 \mu \mathrm{Scm}-1$ are classified as very soft, soft and hard, respectively ${ }^{10}$. Variation in Electrical conductivity in collected water sample were 320 to 542 $\mu \mathrm{mhos} / \mathrm{cm}$ (September pre-immersion period); 638 to $758 \mu \mathrm{mhos} / \mathrm{cm}$ (October immersion period) and 714 to 810 $\mu \mathrm{mhos} / \mathrm{cm}$ (November. post-immersion period) respectively.

\section{Total Solids and Total Dissolve Solids}

The amount of total dissolve solids (TDS) in water indicates salinity of water and may also be used as an indicator for rapid plankton growth and sewage contamination. The total dissolved solids in water comprise mainly of inorganic salts and small amount of organic matter such as carbonate, bicarbonate, chloride, sulphate, nitrate, 
sodium, potassium, calcium and magnesium. The total dissolved solids in water originate from natural sources and depend upon location, geological nature of the pond, drainage, rainfall, bottom deposit and inflowing water ${ }^{11}$. Total Solids was found to be higher during immersion of idols. The high values of Total Solids maybe due to deposition of inorganic salts and organic matter and idol immersion activities in Dulahra pond. Variation in total dissolved solid in collected water sample were 280.72 to $376.17 \mathrm{mg} / \mathrm{L}$ (September pre-immersion period292.62 to $760.18 \mathrm{mg} / \mathrm{L}$ (September, immersion period) and 388.84 to $989.16 \mathrm{mg} / \mathrm{L}$ (October, post-immersion period) respectively.

\section{Total Hardness}

Hardness is the result of positive ions dissolved in water such as $\mathrm{Ca}^{++}, \mathrm{Mg}^{++}, \mathrm{Sr}^{++}, \mathrm{Fe}^{++} \mathrm{Mn}^{++}$. In addition to these cations, some anions (mainly $\mathrm{SO} 4{ }^{2-} \mathrm{Cl}^{-} \mathrm{NO}^{3-}$ and $\mathrm{SiO}^{3-}$ ) naturally exist in water. In pond water are generally present in high amount of calcium and bicarbonate ions. Variation in total hardness in collected water sample were 122.32 to $170.32 \mathrm{mg} / \mathrm{L}$ (September pre-immersion period); 280.12 to $468.16 \mathrm{mg} / \mathrm{L}$ (October, immersion period) and 178.24 to $312.31 \mathrm{mg} / \mathrm{L}$ (November, post-immersion period) respectively.

\section{Total Alkalinity}

The lower values of total alkalinity during September month may be due to the utilization of $\mathrm{CO} 2$ during phytoplankton growth as well as the effect of drainage water discharged into the Dulahra Pond. On the other hand, the lower values during October month are mostly due to its assimilation by phytoplankton and aquatic plants during the spring bloom. Some organic matter containing nitrogen usually resists bacterial change and remains in the water or sinks to the sediments as bottom humus ${ }^{12}$. Variation in total alkalinity in collected water sample were 147.06 to $188.22 \mathrm{mg} / \mathrm{L}$ (September, pre-immersion period); 272.64 to $362.42 \mathrm{mg} / \mathrm{L}$ (October, immersion period) and 154.62 to $255.20 \mathrm{mg} / \mathrm{L}$ (November, post-immersion period) respectively.

\section{Chloride}

The high concentration of chloride is considered to be an indication of pollution due to high organic waste of animal origin. Variation in chloride in collected water sample were 58.31 to $66.42 \mathrm{mg} / \mathrm{L}$ (September, pre-immersion period)); 74.48 to $80.84 \mathrm{mg} / \mathrm{L}$ (October immersion period) and 88.12 to $116.12 \mathrm{mg} / \mathrm{L}$ (November, post-immersion period) respectively.

\section{Sulphate}

Sulphate, the predominant form of sulphur in an aquatic ecosystem, is of immense importance as it affects ecosystem productivity, abundance and distribution of biota etc. Nearly all assimilation of sulphur takes place as sulphates but during decomposition of organic matter, sulphur is reduced to hydrogen sulphide which is oxidized rapidly. In an aquatic environment, sulphate do not limit the growth and distribution of biota. Variation in sulphate in collected water sample were 12.46 to $17.62 \mathrm{mg} / \mathrm{L}$ (September, pre-immersion period); 44.26 to $77.18 \mathrm{mg} / \mathrm{L}$ (October immersion period) and 39.68 to $81.64 \mathrm{mg} / \mathrm{L}$ (November, post-immersion period) respectively.

\section{Nitrate (NO3-):}

Nitrate occurs in water from various natural sources and due to human activities like food production, agriculture and manure disposal of domestic and industrial sewage. High level of nitrates is found in rural areas because of extensive application of nitrogenous fertilizers in agriculture. In urban areas sewage water rich in nitrates contaminate surface water thus increases the nitrate amount. Nitrate stimulates the growth of hydrophytes and phytoplankton that consequently increase the nutrient in water body leading to eutrophication. Variation in nitrate in collected water sample were 12 to $22 \mathrm{mg} / \mathrm{L}$ (September pre-immersion period); 52 to $65 \mathrm{mg} / \mathrm{L}$ (October immersion period) and 46 to $58 \mathrm{mg} / \mathrm{L}$ (November, post-immersion period) respectively.

\section{Fluoride}

Fluoride is a trace element typically present in water at levels from 0.1 to $1.5 \mathrm{mg} / \mathrm{L}$. It may be added excess to water as a measure to prevent tooth decay in humans ( 0.7 to $1.2 \mathrm{mg} / \mathrm{L}$ ). Levels at or above $3 \mathrm{mg} / \mathrm{l}$ are reported to cause losses of some fish species, depending upon complex water conditions. Variation in fluoride in collected water sample were 0.48 to $0.62 \mathrm{mg} / \mathrm{L}$ (September, pre-immersion period); 0.62 to $1.12 \mathrm{mg} / \mathrm{L}$ (October immersion period) and 0.49 to $1.4 \mathrm{mg} / \mathrm{L}$ (November, post-immersion period) respectively

\section{Biochemical oxygen demand (BOD)}

BOD and COD are important parameters that indicate contamination with organic wastes. Biochemical oxygen demand (BOD) is the amount of oxygen required by bacteria while stabilizing decomposable organic matter under 
aerobic condition. It is required to assess the pollution of surface and ground water contamination occurred due to disposal of domestic and industrial effluents. According to WHO drinking water standard, BOD should not exceed 6 $\mathrm{mg} / \mathrm{L}$. Variation in biochemical oxygen demand in collected water sample were 12.0 to $22.0 \mathrm{mg} / \mathrm{L}$ (September, preimmersion period); 34.0 to $56.0 \mathrm{mg} / \mathrm{L}$ (October immersion period) and 26.0 to $62.0 \mathrm{mg} / \mathrm{L}$ (November, postimmersion period) respectively. Every year ,after Gnesh pooja,Durga Puja and Kali puja the biological oxygen demand (BOD) levels in pond increase, dramatically.

\section{Chemical oxygen demand (COD)}

Chemical oxygen demand (COD) determines the oxygen required for chemical oxidation of most organic matter and oxidizable inorganic substances with the help of strong chemical oxidant. In conjunction with the BOD, the COD test is helpful in indicating toxic conditions and the presence of biologically resistant organic substances. Variation in chemical oxygen demand in collected water sample were 64.0 to $78.0 \mathrm{mg} / \mathrm{L}$ (September, pre-immersion Period); 84.0 to $110.0 \mathrm{mg} / \mathrm{L}$ (October immersion period) and 76.0 to $98.0 \mathrm{mg} / \mathrm{L}$ (November post-immersion period) respectively.

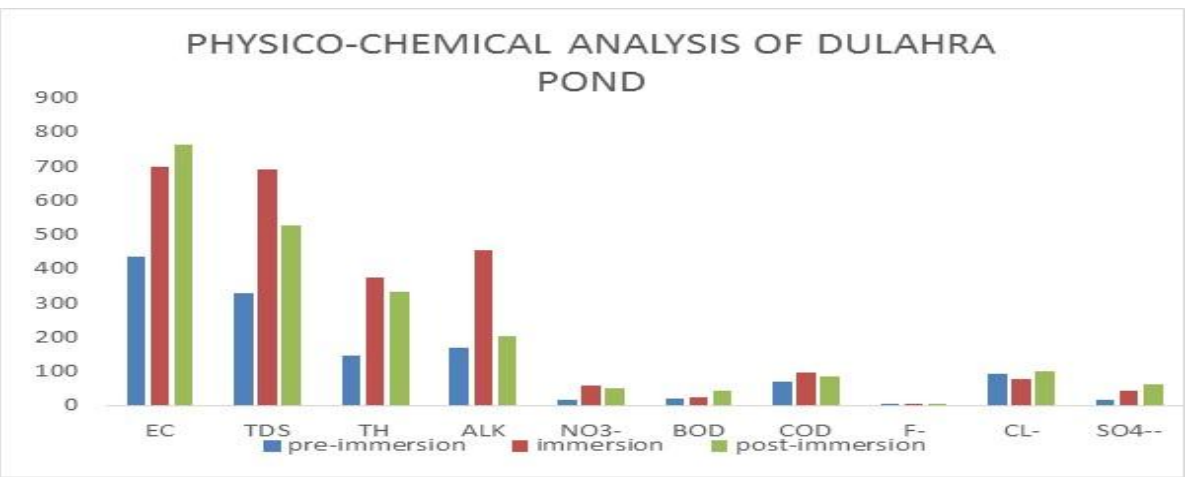

Fig 4:-Average physic-chemical variation in collected Dulahra pond water

\section{Water quality index:}

Water quality index (WQI) is defined as a rating reflecting the composite influence of different water quality parameters on the overall quality of water. Chemical analysis of water gives a concept about its physical and chemical composition by some numerical values but for estimating exact quality of water, it is better to depend on water quality index which gives the idea of quality of drinking water. The rating of water quality index (WQI) is shown

below ${ }^{12}$ :

Table 1.1-Classification of Water Quality Index

\begin{tabular}{|l|l|}
\hline Water Quality Index & Water Quality Status \\
\hline $95-100$ & Excellent water quality \\
\hline $89-94$ & Very Good water quality \\
\hline $80-88$ & Good water quality \\
\hline $65-79$ & Fair water quality \\
\hline $45-64$ & Marginal water quality \\
\hline $0-44$ & Poor water quality \\
\hline
\end{tabular}

The present study showed variation of water quality index in Dulahra pond water ranging from 62.28 to 69.84(preimmersion period), 58.27to 64.16(immersion period) and 38.27to 44.16 (post-immersion period) falls under simply good to poor water category. 
The WQI has been calculated from the point of view of the suitability of pond water for human consumption. It is well known that the more harmful a given pollutant is the smaller is its permissible value for domestic use water. Water can be utilized for various purposes based on various water quality parameters, Such as $\mathrm{pH}$ value, transparency, dissolved oxygen, electrical conductivity, TDS, BOD, COD, Nitrates, fluoride, sulphates are analyzed to check suitability of water for domestic and industrial purpose, aquatic organisms, agriculture uses. Festivals are an important part of rich and diverse cultural heritage of India. Idol worship has been in the practice in India since ancient time. To worship god and goddess only natural things like milk, curd, ghee, coconut, beetle, and pond water were usually used. In India idol immersion is another anthropogenic activity. The idols of Lord Viswakarma, Lord Ganesh, Lord Krishna, Goddess Durga etc. are worshipped with all rituals by Hindu are immersed in water bodies between the months of August-September to October-November in every year.so now a present day scenario, metals, ornaments, oily substances, synthetic colors, chemical are used to make polish and decorate these idols for worship followed by immersion of these idols in our surrounding aquatic environment which gets polluted to our environment. When the idols are immersed in water bodies, their colors, chemicals, and other components that are used for idol preparation get dissolved and lead to significant changes in the water quality ${ }^{13}$. The floating substances released by idol in the ponds after decomposition result in starts of eutrophication. Thus too many religious activities and religious fanatics have now become a major threat to the ecosystem.

\section{Conclusions:-}

The water pollution level increases in Dulahra pond due to religious activities and cause adverse effect to the aquatic animals and entire aquatic ecosystem. Far greater impact of pollution is seen during the festival season, when immersion of idols in these natural aquatic ecosystems destroyed the whole ecological balance. The water quality parameters have shown significant increase during and after immersion of idols and then declined in the post immersion period.. The results indicated that immersion of a large number of idols during Ganesh chaturthi and devi puja time had already affected the water quality. Immersion of these idols poisons the water of Dulahra pond by increasing acidity and the content of heavy metals ${ }^{14}$. Heavy metal pollution caused by idol immersion can damage the ecosystem as it kills of aquatic animals, fishes, damages plants, blocks the natural flow of water, causing stagnation. The study investigate that this releases 8.8 tone of paints and oil and 20 tonnes of colours in the water .These colours contain a large amount of heavy metals like lead, mercury, cadmium manganese and chromium. The study also found that during festival time, oil and grease in the pond increased by $.86 \mathrm{mg} / \mathrm{l}$ and concentration of heavy metals increased by $0.104 \mathrm{mg} / \mathrm{l}$.

\section{Suggestion}

Regular monitoring of pond water and applying appropriate corrective actions such as immersion of statues should be stopped and use lead-free colours in idols, recycling of the pond water, discharging of treated water in the pond. This will help in improving the water quality of the pond.

\section{Acknowledgement:-}

The author is thankful to the Attal Bihari Vajpayee University, Bilaspur c.g.for providing necessary facilities for carrying out laboratory work. And the support from State planning commission Raipur (Chhattisgarh) for the financial assistance in form of Major Research Project.

\section{References:-}

1. Wagh G.S, Sayyed M.R.G, Sayadi M. H (2014), Evaluating groundwater pollution using statistical analysis of hydro chemical data: A case study from southeaster part of Pune metropolitan city (India), International Journal of Geometrics and Geosciences, 4(3), 456-476.

2. Amruta Amit Joshi, "Water Quality Monitoring System Using Zig-Bee and Solar Power Supply", International Journal of Advanced Research in Electrical, Electronics and Instrumentation Engineering (An ISO $3297: 2007$ Certified Organization) Vol. 4.

3. Trivedy, R.K. and Goel, P.K. : Chemical and biological methods for water pollution studies. Environ. Pub. Karad, India. pp. 1-23 (1986).

4. Manivaskam, N: Physico chemical examination of water, sewage and industrial effluents. Pragati Prakashan, Merrut (2000).

5. S. P. Pande, V.S. Narayanswami, and M. Z. Hasan, Indian, J. Environ. Hlth., 1979, 21(1), 35

6. "Water Quality: Temperature, ph and Dissolved Oxygen", Developed by Vancouver Water Resources Education Center with funding from the WA Department of Ecology 
7. Said, Ahmed, David K. Stevens and Gerald Sehilke: Publications of Sam- Environmental Technolgoy Centre. Istanbul 1999.

8. Sawyer C N, McCarthy P L Chemistry for environmental engineering, 3rd edn. McGraw-Hill Book Company, New York, (1978)

9. Bureau of Indian Standards (BIS) (1998) Drinking water specifications, IS: 10500, 2003

10. Hutter, L.A.: Water and water research. Otto Salle Verlag, Verlag Sauerlonder 1992

11. Tiwari, T.N. and Ali, M. : Water quality index for Indian rivers. In ecology and pollution of Indian rivers. Ashish Publication House, New Delhi. Pp.271-286 (1988).

12. Sinha, S.K. : Portability of some rural ponds water at Muzaffarpur - A note on water quality index. Poll. Res. 14(1), 135-140 (1995).

13. Dr Leena Deshpande, "Water Quality Analysis Laboratory Methods", National Environmental Engineering Research Institute (NEERI), Nagpur Council of Scientific \& Industrial Research, New Delhi, Govt. Of India

14. Kildea, T.N., and Andreacchio L. (2012) Adelaide Desalination Project: Salinity, ph and dissolved oxygen water quality data, marine exclusion zone. March 2012. Australian Water Quality Centre, Adelaide. 10 pp.

15. Naik, S. and Purohit, K.M. : Physico-chemical analysis of some community ponds of Rourkela. Indian J. Environmental Protection. 16(9), 679-684 (1996). 